\title{
Três pretos tristes: André Rebouças, Cruz e Sousa e Lima Barreto
}

\author{
Maria Alice Rezende de Carvalho*
}

\section{RESUMO}

A principal sugestão deste ensaio é a de que a questão da abertura, da incompletude do Brasil foi construída no âmbito dos debates sobre a crise estrutural do império brasileiro, como crítica assistemática, porém pertinaz, à ordem burguesa que se impunha. Naquele contexto, foram portadores dessa crítica André Rebouças, Cruz e Sousa e Lima Barreto, cuja inscrição marginal em seus respectivos contextos de atuação lhes conferiu ângulos privilegiados para a figuração de outros Brasis possíveis. Contudo, o desfecho trágico de suas vidas — o suicídio, a tuberculose famélica e o alcoolismo - ocultou a radicalidade presente em sua obra.

Palavras-chave: André Rebouças; Cruz e Sousa; Lima Barreto; intelectuais negros.

\section{ABSTRACT}

This paper's key proposition is that the issue of openness, of incompleteness of Brazil was built within the debates about the Brazilian Empire's structural crisis as an asystematic though persistent criticism to the imposed bourgeois order. In that context, André Rebouças, Cruz e Sousa, and Lima Barreto were the bearers of such criticism, but their marginal inscription in their respective contexts conferred them privileged angles to figure out other possible Brazils. However, the tragic outcome of their lives — suicide, starving tuberculosis, and alcoholism — hid their works' radicality.

Keywords: André Rebouças; Cruz e Sousa; Lima Barreto; Black intellectuals.

\section{RESUMEN}

La principal sugerencia de este ensayo es que la cuestión de la abertura, de la incompletud de Brasil ha sido construida en el ámbito de los debates sobre la crisis estructural del Imperio brasileño, como crítica asistemática pero pertinaz al orden burgués que se imponía. En aquel contexto, los portadores de esta crítica fueron André Rebouças, Cruz e Sousa y Lima

DOI - http://dx.doi.org/10.1590/2237-101X0183401

Artigo recebido em 6 de dezembro de 2016 e aprovado para publicação em 17 de janeiro de 2017.

* Professora na Pontifícia Universidade Católica do Rio de Janeiro. Rio de Janeiro - RJ, Brasil.. E-mail: malice@puc-rio.br. 
Barreto. La inscripción marginal de los tres en sus respectivos contextos de actuación les ha conferido ángulos privilegiados para la figuración de otros Brasiles posibles. Sin embargo, el desenlace trágico de sus vidas - el suicidio, la tuberculosis famélica y el alcoholismo- ha ocultado la radicalidad presente en sus obras.

Palabras clave: André Rebouças; Cruz e Sousa; Lima Barreto; intelectuales negros.

1.

André Pinto Rebouças (1838-1898), baiano, mulato, engenheiro e professor da Escola Politécnica; João da Cruz e Sousa (1861-1898), negro, catarinense, poeta e funcionário da Estrada de Ferro Central do Brasil; e Afonso Henrique de Lima Barreto (1881-1922), mulato, carioca, jornalista, escritor e funcionário do Ministério da Guerra pertenceram a três geraçóes sucessivas de intelectuais, viveram modestamente e tiveram suas vidas abreviadas pelo suicídio, pela tuberculose famélica e pelo alcoolismo.

Este artigo fala de mortos que, quando vivos, se equilibraram no delicado fio que separou experiência e imaginação, hierarquia e mediação, ricos e pobres, negros e brancos no Império do Brasil. E tem o propósito de relembrar uma perspectiva de país distinta daquela articulada pelo reformismo da geração de $1870 .{ }^{1}$ Críticos também do status quo e igualmente cosmopolitas, esses três intelectuais, contudo, náo tinham a certeza empunhada pelos reformadores quanto à positividade das transformaçôes burguesas em curso no mundo. Em suas obras prevalecem referências à liberdade comunitária, distinta daquela regida pelo liberalismo, noçóes protossocialistas e diç̧áo decadentista. Na verdade, o destaque que a historiografia conferiu ao empuxo modernizante da chamada geração de 1870 foi de tal calibre que terminou por apagar outros sintomas presentes na conjuntura e outras representaçóes do país, mesmo que tais representaçôes continuem operando, ainda hoje, entre nós.

Em outras palavras, este artigo pretende investir em um tipo de imaginação social que, vigente no Brasil desde o último quarto do século XIX, difere bastante do programa cognitivo e normativo que, por aquela época, se estabilizara no ocidente europeu e se estendia a outras partes do mundo. ${ }^{2}$ E pretende associá-la a intelectuais que experimentaram certa marginalização no ambiente público-político brasileiro, seja por sua atuação política, por seus valores estéticos, por sua boemia em um contexto de profissionalizaçấo crescente da atividade intelectual, ou por sua cor, combinada a uma desafiante autoconfiança que ostentaram quando jovens. O tempo moeu seus sonhos de reconhecimento e projeção, com

\footnotetext{
${ }^{1}$ ALONSO, Ângela. Ideias em movimento. A geração de 1870 na crise do Brasil-Império. Rio de Janeiro: Paz e Terra, 2002.

2 POLANYI, Karl. A grande transformação. As origens da nossa época. Rio de Janeiro: Campus, 1980.
} 
exceção, talvez, de Rebouças, cujos laços com d. Pedro II se estreitaram progressivamente e lhe conferiram algum conforto existencial em sua idade madura, até, pelo menos, o final do império. André Rebouças terá sido, por isso, o que menos experimentou a marginalidade intelectual e o que mais vivenciou as ambiguidades decorrentes da sua inscrição social. Quando jovem e lobista de projetos de construção civil protagonizou muitas mediaçóes entre interesses que afetavam as elites políticas brasileiras, tornando-se conhecido no ambiente da Corte. Quando mais velho, abolicionista e achegado ao círculo de interlocutores do imperador, sua posição lhe facultou o reconhecimento de lideranças do movimento, como Joaquim Nabuco e José do Patrocínio, tornando-se, a um só tempo, intelectual palaciano e crítico pertinaz do sistema socioprodutivo que sustentava o império.

Tomá-los como grupo, embora estivessem separados entre si por intervalos de duas décadas, é um artifício metodológico que tem como objetivo sublinhar a permanência de uma visão comum acerca do Brasil, a marginalização que foi infringida a essa representação do país em diferentes contextos e os efeitos contínuos desse processo sobre cada um dos protagonistas. Dessa visão comum se destaca, principalmente, a crítica ao imobilismo que imputavam à vida brasileira, referido explicitamente por Rebouças — "Ah, meu bom Deus [...] é impossível fazer caminhar esse país..." 3 - e evocado por Cruz e Sousa como elemento constitutivo da sua poética.

De fato, desde muito jovens, o imobilismo brasileiro era sentido por aqueles intelectuais como um entrave às suas potencialidades. Pressentiam, porém, o risco contido na rejeição àquele ambiente institucional que lhes facultara as posiçóes de que desfrutavam. A tensão transparece no poema de Cruz e Sousa, "Emparedado", do livro Evocaçóes, em que a crítica a uma "ciência" que nega aos negros as funçóes do entendimento artístico é temperada pela cautela, que o adverte: “[...] Esperar, esperar, esperar". ${ }^{4}$ Também Lima Barreto, nascido em contexto de franco declínio da monarquia, quando já não podia vivenciar plenamente o imobilismo, comprovou serem acertados os temores pressentidos principalmente por Rebouças, pois conheceu perdas dramáticas decorrentes da transição institucional da monarquia à república, quando sua família viu desaparecerem certas garantias que lhe facultava o visconde de Ouro Preto, último presidente do Conselho de Ministros do império.

Portanto, as tensóes inerentes às respectivas inscriçóes daqueles intelectuais na vida brasileira explicam não apenas a sua resistência ao imobilismo imperial, mas também a sua recusa às vertentes dominantes da crítica ao império, regidas pelo liberalismo em voga no mundo. A operação intelectual possível, nesse quadro, era a que consagrava o elogio ao dinamismo, sem uma substantivação do que deveria advir em consequência. ${ }^{5}$

\footnotetext{
${ }^{3}$ REBOUÇAS, André. Diário, 31/08/1870. In: CARVALHO, Maria Alice Rezende de. O quinto século. André Rebouças e a construção do Brasil. Rio de Janeiro: Revan, 1998, p. 140.

${ }^{4}$ GUIMARÃES, Julio Castañon. Simbolismo e Cruz e Sousa. In: CRUZ E SOUSA. Últimos sonetos. 2. ediçáo crítica e revista, com nota introdutória de Adriano da Gama Kury. Florianópolis/Rio de Janeiro: Editora da UFSC-Fundação Catarinense de Cultura/Fundação Casa de Rui Barbosa.

${ }^{5}$ CARVALHO, Maria Alice Rezende de. Intelectuales negros en el Brasil del siglo XIX. In: ALTAMIRAN-
} 
A existência de um partido intelectual como esse, que fazia do dinamismo um ideal, pode ser entendida como esforço de contenção do novo projeto civilizatório que se desenhava para o Brasil. Contudo, empenhados apenas em imprimir negatividade a ele, seus autores se mantiveram próximos de filosofias da história, quando o mundo já se alinhava pela sociologia — um saber voltado à reprodução de sua dinâmica. Desse modo, a dimensão política de suas intervençôes não seria percebida ou, se foi, não seria incorporada ao acervo reflexivo sobre os impasses da formação brasileira. Perdeu-se, antes, como expressão excêntrica ou marginal de intelectuais pretos e mulatos, identificados com o império. A reconstrução desse partido é, enfim, o que orienta a seleção dos três intelectuais, cujas vidas foram tão dramaticamente afetadas por suas figuraçóes do Brasil.

2.

Nascido em 1838, na cidade de Cachoeira, no Recôncavo baiano, André Rebouças era filho de Carolina Pinto Rebouças, branca, de família de comerciantes, e Antônio Pereira Rebouças, mulato, que ainda jovem auferira grande prestígio na Corte de $\mathrm{d}$. Pedro I como herói das lutas provinciais pela independência do Brasil. No dia do nascimento de seu primogênito (13/01/1838), novamente a Bahia se encontrava agitada militarmente pela Sabinada, uma das insurreições regionais que caracterizaram o período de menoridade de d. Pedro II, e Antônio Rebouças, pai de André, combateria, mais uma vez, ao lado das forças da ordem.

O fato é que, até 1850, em meio à instabilidade que acompanhou a consolidação do Estado imperial, a Província da Bahia era uma das mais importantes regióes do país. A antiga sede da administraçáo colonial chegara ao século XIX com uma economia vigorosa, uma capital habitada por mais de 60 mil habitantes, a segunda maior representação parlamentar na Corte, uma malha urbana comparável à de Minas Gerais, e uma sociedade composta basicamente por pretos e mulatos, escravos ou livres — mais de 70\%, em 1808 -, que se distribuíam em atividades diversas, inclusive como pequenos proprietários de terras, e experimentavam facilidades evidentes em termos de mobilidade social. ${ }^{6}$

A história dos Rebouças ilustra as possibilidades ascensionais que se abriam a famílias pretas e mulatas na Bahia oitocentista. Iniciada pelo alfaiate português Gaspar Pereira Rebouças e pela africana liberta Rita Brasília dos Santos, seus filhos conheceram as seguintes profissóes: um músico, formado em Paris e tornado mestre de Harmonia no Conservatório

DO, Carlos; MYERS, Jorge (Org.). Historia de los intelectuales en America Latina. 1. ed. Buenos Aires; Madri: Katz Editores, 2008, v. 1, p. 312-334.

${ }^{6}$ MATOSO, Kátia. Bahia — século XIX. Uma província no império. Rio de Janeiro: Nova Fronteira, 1992. 
de Bolonha; um médico, professor da Escola de Medicina da Bahia, e, finalmente, o filho mais jovem, Antônio Pereira Rebouças, pai de André, que havia iniciado sua vida profissional como assistente de escrevente em cartórios de Salvador, se tornou jurista, secretário de governo da Província de Sergipe, parlamentar na Corte e conselheiro do império. ${ }^{7}$

João da Cruz nasceu em 1861, em Desterro, atual Florianópolis, capital da Província de Santa Catarina, filho do mestre-pedreiro Guilherme da Cruz e de Carolina Eva da Conceiçáo, ambos africanos, escravos do coronel Guilherme Xavier de Sousa. A exemplo do pai de André Rebouças, embora separados por algumas décadas, o coronel Guilherme Xavier de Sousa também gozava de enorme prestígio na Corte, em virtude de feitos militares contra Manuel Oribe, na região platina. Sem filhos, ele e sua esposa assumiram a educação do menino João da Cruz, que com eles viveu até a morte do militar, tornado marechal por atos de bravura na Guerra do Paraguai. Após seu falecimento, pais e irmão de João da Cruz passaram a com ele residir no sobrado de seus pais adotivos, direito que receberam como herança, juntamente com um lote de terra e algum dinheiro. ${ }^{8}$ É nessa época, aos 9 anos de idade, que João da Cruz decide agregar o Sousa a seu nome.

A Província de Santa Catarina, contudo, era quase o oposto simétrico da Bahia. Sem grande projeção econômica, voltada à produçáo de bens de subsistência em pequenas propriedades, era, por qualquer ângulo que se a observasse, acanhada. A sua representação política na Corte contava apenas dois deputados e a região se notabilizava por ser a fronteira avançada do poder central em face da sempre instável situação ao sul. Na década de 1870, Santa Catarina tinha apenas uma escola pública, dois pequenos clubes cívicos para onde convergiam os rapazes instruídos, dois ou três jornais de expressão localíssima, plantéis diminutos de escravos, poucos pretos em geral. Era, em suma, uma sociedade relativamente homogênea, de pequenos produtores, que respirava acomodação. $\mathrm{O}$ movimento, ali, era dado pelo ritmo dos "estrangeiros" aportados: imigrantes de diferentes procedências, governadores e funcionários enviados da Corte, alguns cientistas, sobretudo botânicos interessados em estudar a flora local, como Charles Müller, discípulo de Darwin e professor de Cruz e Sousa, além de engenheiros comissionados pelo estado para restauração de portos e fortalezas, entre eles, o muito jovem André Rebouças, que ali esteve em 1862, um ano após o nascimento do futuro poeta.

\footnotetext{
${ }^{7}$ SPITZER, Leo. Lives in Between. Assimilation and marginality in Austria, Brazil, West Africa. Cambridge: Cambridge University Press, 1989.

${ }^{8}$ MAgAlHÁes Jr., Raimundo. Poesia e vida de Cruz e Sousa. São Paulo: Editora das Américas, 1975. Ler também MERQUIOR, José Guilherme. De Anchieta a Euclides: breve história da literatura brasileira. Rio de Janeiro: José Olympio, 1977.
} 
Lima Barreto nasceu no Rio de Janeiro, em 1881. Foi o primogênito de Manuel Joaquim de Lima Barreto, mulato, descendente de escravos, e de Amália Amanda Barreto, filha de escrava alforriada pela família Mendes de Sousa. Seu pai era tipógrafo, tendo aprendido a profissão no Imperial Instituto Artístico, e sua mãe, professora pública, que veio a falecer quando ele tinha 7 anos de idade. Oriundo também, como Rebouças e Cruz e Sousa, de famílias marcadas pela escravidão, Lima Barreto, diferente deles, nasceu no ambiente da Corte, em um contexto já bastante conturbado pela desagregação do império, cujos sintomas se avolumavam desde meados da década de 1870 . Tais sintomas se traduziram politicamente na substituição imoderada de gabinetes, que resultava em tremenda rotatividade dos cargos públicos, já que a eles só se chegava por indicação de políticos da situação - aspecto contextual que vitimaria seu pai e náo passaria despercebido pelo menino Afonso Henriques.'

$\mathrm{Na}$ Corte, o caminho de ascensão de mulatos pobres também não estava inteiramente vedado..$^{10} \mathrm{O}$ pai de Lima Barreto, por exemplo, chegara a cursar a Escola de Medicina, abandonando-a quando constituiu família. Diferentemente, porém, das províncias, não só a escalada social era ali mais seletiva, porque dependia da aleatoriedade dos encontros interclasses, como também a captura de pobres nessas redes de proteção não guardava o mesmo sentido de horizontalidade presente nas dinâmicas familiares do interior do Brasil. Na Corte, sendo as famílias funcionalmente substituídas pelo braço político das elites senhoriais, a ascensão de pobres indicava um caminho de subalternidade.

Durante os anos 1870, o tipógrafo Manuel Joaquim trabalhou com o visconde de Ouro Preto, que veio a se tornar padrinho do menino Afonso Henriques e o protegeu mesmo após ter sido banido do Brasil pelos republicanos. Sob esse guarda-chuva, a trajetória juvenil de Lima Barreto foi facilitada, tendo chegado a ingressar na Escola Politécnica na mesma turma de Guilherme Guinle e Eugênio Gudin, exemplares diletos da elite brasileira, em um momento em que a engenharia deixara de ser, como na geração de Rebouças, o desaguadouro dos jovens pobres que desejavam ingressar no ensino superior. Era, agora, uma alternativa para jovens bem posicionados socialmente, com pendores matemáticos. Mulato, vincado pelo estigma da subalternidade, a passagem de Lima Barreto por aquela nova Politécnica foi o ninho do seu ressentimento e não se completou.

3.

Dos três intelectuais aqui apresentados, Rebouças e Cruz e Sousa exibem uma trajetória

\footnotetext{
${ }^{9}$ ASSIS BARBOSA, Francisco de. A vida de Lima Barreto (1881-1922). Rio de Janeiro: Civilização Brasileira, 1964.

${ }^{10}$ CARVAlHO, José Murilo de. Os bestializados. O Rio de Janeiro e a república que não foi. São Paulo: Companhia das Letras, 1987.
} 
inicialmente muito similar. Mulato, o primeiro, preto, o poeta, ambos pertenceram a famílias, por descendência e perfilhamento, com elevado prestígio em suas províncias de origem e mesmo na Corte, decorrente de êxitos militares em episódios cruciais à formação e consolidação do Estado brasileiro.

As diferenças entre suas respectivas trajetórias se acentuam no movimento que realizam em direção à Corte. Rebouças segue para lá aos 8 anos de idade, em um momento de ascensão familiar e quando já se avizinhava a chamada "era" Saquarema - o longo período de estabilização política do império e de fortalecimento de suas instituiçóes. Sua vida profissional, nesse sentido, coincide com o momento de maior impulso econômico e político do Segundo Reinado. Já para o menino João da Cruz, a morte do marechal Guilherme representaria o início de uma trajetória precocemente declinante, com o cancelamento de suas chances de melhor inserção em círculos cultivados da província e a opção, finalmente, por deixá-la, empregando-se em uma Companhia Teatral que por lá passou no início dos anos de 1880. Voltaria a Desterro algumas vezes, trabalhando em jornais abolicionistas, até a sua chegada ao Rio de Janeiro, quando o império já se esgotava. Assim, a sorte de ambos náo derivou apenas de seus respectivos talentos. Pesou o fato de se tornarem adultos em contextos em que o império conhecia sua ascensão, no caso de Rebouças, e sua crise final, no de Cruz e Sousa.

Se a fortuna, desse ponto de vista, não iluminou a trajetória de Cruz e Sousa, menos ainda a de Lima Barreto. Sob a república, as chances de mobilidade social experimentadas por pretos e mulatos instruídos na Capital Federal viram-se diminuídas, pois a crescente centralidade do mercado como coordenador da vida social, se náo eliminou os nexos tradicionais entre política e cultura, os abateu significativamente. Nesse sentido, a reivindicação de Lima Barreto por uma "literatura militante" ecoa o sentimento da necessidade de recuperação da dimensão pública no âmbito das letras e das artes, como condição de possibilidade da existência de intelectuais com o seu perfil. Ademais, o império escravista não conhecera a tematização da questão racial. Emergente, porém, no Brasil republicano, o tema da raça involucrado pelo cientificismo escalou uma posição reflexiva, que se observa nos debates envolvendo médicos, criminalistas, políticos e a psicologia social em voga no período, com efeitos incontornáveis para pretos e mulatos brasileiros. ${ }^{11}$

Pensar, pois, a evolução política do Brasil vis-à-vis à trajetória desses intelectuais significa algumas coisas. A primeira delas, a opção por combinar metodologicamente duas perspectivas analíticas distintas e complementares - a que apresenta uma dimensão estrutural do Oitocentos brasileiro e aquela que traduz o impacto dessa dimensão nas estratégias individuais, apostas e resultados vivenciados por três personagens paradigmáticos.

Significa, além disso, compreender o tipo de relação que se estabelecia entre o centro e a

\footnotetext{
${ }^{11}$ SCHWARCZ, Lilia Moritz. O espetáculo das raças: cientistas, instituiçôes e a questão racial no Brasil, 1870-1930. São Paulo: Companhia das Letras, 1993.
} 
periferia do império, tanto do ponto de vista geográfico quanto do ponto de vista social. Afinal, concebido e organizado segundo a perspectiva que lastreara o absolutismo português, o Estado brasileiro, em pleno século XIX, atualizou a tópica que prescrevia a preservaçáo do dominium dos súditos com o incremento simultâneo do poder do rei — aparente paradoxo, que só poderia ser sanado mediante a agregação material e simbólica de espaços inéditos, sobre os quais o baronato não detinha poder e, consequentemente, não podia disputar com o monarca.

Assim, se no contexto do renascimento lusitano isso se traduziu na incorporação de novos territórios na África, na América e no Oriente, no âmbito do Estado nacional brasileiro consistirá no duplo preceito da defesa da unidade territorial - que conferia reservas de soberania ao monarca - e da criação de símbolos de poder exclusivos ao rei, desde a concessão de títulos e comendas até a ampliação de quadros do funcionalismo e a democratização do acesso a eles mediante a extensão da instrução pública, a formação de artífices e gráficos, a instituição de agências organizadoras de intelectuais e artistas sob o padrão das Academias, a valorização, enfim, da engenharia militar e dos engenheiros. ${ }^{12}$

O fato é que a atribuição de uma dimensão pública às profissões intelectuais, sendo um artifício monárquico para driblar disputas jurisdicionais com as classes dominantes, foi também uma porta de oportunidades para os que souberam transpô-la. É esse o quadro institucional que pode explicar a articulaçáo entre política e cultura ao longo do século XIX e, principalmente, a emergência de intelectuais pretos e mulatos que, não obstante as restriçôes do meio, manipulavam com destreza o repertório cultural em circulação no eixo dinâmico do Ocidente moderno. Tal quadro não sobreviveria à república.

Juntos, portanto, Rebouças, Cruz e Sousa e Lima Barreto representam certo andamento do processo de formaçáo de intelectuais pretos e mulatos no Brasil. Vivendo em três momentos distintos, experimentaram possibilidades de inscrição no mundo muito diversas. Semelhantes na origem, diferentes no entrecho de suas vidas, voltam a se encontrar como expressóes de uma perspectiva intelectual e politicamente derrotada.

4.

Em meados de 1870, quando tem início o movimento pela reforma das instituiçóes do império, Cruz e Sousa era um menino e Lima Barreto ainda não era nascido. Rebouças, porém, já experimentava, aos 30 anos de idade, sucessos e frustraçóes como engenheiro e concessionário de obras públicas. Será ele, portanto, dentre os três, a viver as tensôes mais agudas, inerentes à posição que os caracterizaria.

\footnotetext{
${ }^{12}$ BARBOZA FILHO, Ruben. Tradição e artifício. Iberismo e barroco na formação americana. Belo Horizonte: Editora da UFMG, 1999.
} 
Examinado em perspectiva, o desencontro entre as concepçôes dominantes no campo reformista e as expectativas de André Rebouças derivavam, crucialmente, de seus diferentes planos de enunciação. Ambos esgrimiam argumentos contra a ordem política excessivamente centralizada e contra os efeitos institucionais, intelectuais e morais do domínio Saquarema, a que responsabilizavam pela natureza imobilista, letárgica, do império brasileiro. Divergiam, porém, pelo fato de os reformadores se aterem ao projeto de modernização das instituiçôes políticas, enquanto, para Rebouças, o problema estava na própria formação social brasileira, que nos legara o latifúndio e a escravidáo — origem do pathos que caracterizava as elites políticas do país. Sua participaçáo no campo político-intelectual do reformismo era assim dificultada por considerá-lo inócuo. Para Rebouças tratava-se de redesenhar a sociedade liberando-a de seu enrijecimento, evidenciado, aliás, segundo ele, no bloqueio constante dos projetos que formulava como engenheiro e empresário da construção civil.

A posição de Rebouças, naquele contexto, era tensionada pela duplicidade da sua inscrição. De um lado, circulava com desenvoltura entre os membros da elite por força do prestígio de seu pai, por seus próprios méritos, inclusive militares, demonstrados na Guerra do Paraguai, e pelas graças do visconde de Itaboraí, ministro do império e admirador do jovem mulato, a quem chamava de "meu inglês". ${ }^{13}$ Como consequência, frequentava o círculo social mais elevado da Corte, cultivava amizades e inimizades entre parlamentares de ambos os partidos e desfrutava de uma situação economicamente confortável. Por outro lado, era engenheiro militar, o que, na sua geração, denotava uma origem social modesta; era pressionado por constante insegurança material, derivada de sua condição de arrimo de família e responsável pelo sustento de sobrinhos órfãos; alimentava uma disfarçada inclinação pela Igreja reformada em ambiente que associava prestígio social e convicção católica; era lobista na Câmara dos Deputados, instância na qual se decidiam as concessôes de obras públicas e cenário de constantes rituais de humilhação, já que, no Brasil, tal prática era destituída da dignidade legal que conhecia nos Estados Unidos; e, por fim, tinha na pele, além da ancestralidade escrava, as feias cicatrizes que lhe legara a varíola contraída na infância.

Republicano nos anos 1870, foi leitor da historiografia referente à guerra civil inglesa do século XVII. E dessa incursão extrairia uma noção de liberdade preexistente ao liberalismo, como sinônimo de autonomia do produtor-proprietário. Uma liberdade, enfim, materialmente fundada, que Rebouças acreditava ser a base da energia social presente na sociedade norte-americana desde a colonização, com sua fronteira aberta pelos puritanos ingleses que para lá se dirigiram..$^{14}$ Os Estados Unidos, para Rebouças, eram, pois, uma continuação da revolução agrária iniciada na Inglaterra, que imprimia no novo continente os signos permanentes do movimento, do risco e da inovação. Assim, ao lado de suas fraturas de natureza social, Rebouças agregaria, por aquela época, novos impasses, derivados dessa aquisição

\footnotetext{
${ }^{13}$ CARVALHO, Maria Alice Rezende de. O quinto século, op. cit.

${ }^{14}$ SKINNER, Quentin. Liberdade antes do liberalismo. Sáo Paulo: Editora Unesp, 1999.
} 
intelectual. Porque, em que pesem todas as suas diferenças em relação aos reformadores brasileiros, tinha, como eles, horror à guerra civil — essa, aliás, uma das poucas afinidades genuínas entre Rebouças e os liberais de seu tempo: ambos temiam a luta fratricida; temiam jogar o Brasil em uma crise similar àquela do período regencial.

O movimento abolicionista, aquecido no início dos anos de 1880 , viria a dar encaminhamento a alguns de seus impasses. Em primeiro lugar, porque tal movimento se apresentou como "causa nacional" e, nessa condição, favoreceu a participaçáo de atores que, como Rebouças, guardavam alguma distância em relação ao campo dominante do reformismo. Mas principalmente porque lhe propiciou um engajamento integral, tornando-se responsável pela organização de conferências e meetings e se convencendo, progressivamente, da viabilidade de uma "monarquia republicana", cujo exemplo era a Inglaterra de seus dias. Assim, na década de 1880, quando a propaganda republicana extrapolou os limites do reformismo, Rebouças será um dos mais ativos defensores da monarquia. Via na república defendida pelos cafeicultores paulistas o interesse na preservação do monopólio da terra e, portanto, um retrocesso no lento andamento das aspiraçóes democráticas, que preconizavam o fim do trabalho escravo e o concomitante acesso à terra — condição necessária à plena autonomização do produtor rural.

Rebouças se torna, então, amigo do imperador, cujos movimentos após a abolição da escravatura indicavam crescente preocupação com o censo territorial brasileiro e uma possível revisão da lei agrária. ${ }^{15}$ A proclamação da república, segundo o engenheiro, terá interrompido a marcha da democratização do império, levando-o a seguir para a Europa com d. Pedro II e a família imperial. E a história do engenheiro se fecha em seu autoexílio, após muitas cartas trocadas com Nabuco, nas quais sugere que o grande abolicionista assumisse uma crítica mais firme à "escravização" do solo brasileiro, que impedia a autonomia dos produtores rurais e condenava negros e imigrantes brancos à servidão.

Nos seus últimos anos de vida, André Rebouças se referia ao Brasil como uma civilização extinta, tal como a Grécia antiga. Extinguira-se porque, quando posta diante da possibilidade de superar o último travo colonial — o monopólio da terra — insistiu em mantê-lo. Morto o Brasil, matou-se também em Funchal, Cabo Verde, atirando-se de um penhasco no oceano Atlântico, em 1898.

Nos anos de maior agitação política na Corte, principalmente o de 1888, chegava Cruz e Sousa ao Rio de Janeiro, aos 27 anos de idade, com dinheiro tomado emprestado a Germano Wendhausen, deputado e líder abolicionista na Assembleia Legislativa Provincial de Santa Catarina, e uma carta de apresentação ao então senador Alfredo Taunay, do Partido Conservador. Taunay fora nomeado presidente da Província de Santa Catarina, em 1876,

\footnotetext{
${ }^{15}$ VERÍSSIMO, Inácio José. André Rebouças através de sua autobiografia. Rio de Janeiro: José Olympio Editora, 1939. E também CARVALHO, Maria Alice Rezende de. André Rebouças e a questão da liberdade. In: BOTELHO, André; SCHWARCZ, Lilia Moritz (Org.). Um enigma chamado Brasil. 29 intérpretes e um país. São Paulo: Companhia das Letras, 2009.
} 
e eleito deputado geral, em 1886, pelo Primeiro Distrito daquela província, tornando-se senador no mesmo ano, na vaga do então falecido barão de Laguna, único representante da região no Senado. Por essa razão, seus eleitores, amigos de Cruz e Sousa, recomendaram-no ao político. Mas o contato entre eles não prosperou: "Nem ao menos me mandou entrar, procedimento esse que me autorizou a não voltar mais à casa de tal senhor. Embora eu precise fazer carreira, não necessito, porém, ser maltratado". ${ }^{16}$

A partida de Cruz e Sousa para o Rio de Janeiro obedeceu ao impulso de um jovem socialmente confiante, embora pobre, que sonha com as oportunidades oferecidas pela grande cidade. Testemunhas da sua trajetória surpreendem-no, no início da década de 1880, cultivando as características de um dândi em Desterro: extravagante e fantasista na forma de vestir, caprichoso e excêntrico, cosmopolita em uma província periférica, desdenhoso do farisaísmo local, como o eram les poètes maudits. Descrevem-no, além disso, esperançoso quanto ao seu triunfo e bem-humorado. ${ }^{17}$ Via-se, ademais como ariano, por sua filiação à grande cultura, e, provavelmente, apenas na Corte terá percebido ser negro. De lá, escrevendo a seu amigo Virgílio Várzea, em janeiro de 1889, apontou: "Não há por onde seguir. Todas as portas e atalhos estáo fechados ao caminho da vida e para mim, pobre artista ariano, ariano sim porque adquiri, por adoção sistemática, as qualidades altas dessa grande raça [...]". ${ }^{18}$

Pouco depois de sua chegada, no cenário de um Rio de Janeiro recém-tornado capital da república, o jovem poeta não conheceria entrada. Embora abolicionista militante, não participara das lutas abolicionistas na Corte, que o teriam aproximado de círculos mais permeáveis à participação de negros instruídos e o acolhido nas agências que estruturavam o debate público, tais como jornais, cafés, revistas literárias e clubes cívicos. Vivera os anos da campanha abolicionista sem pouso certo, circulando por várias cidades brasileiras, de Porto Alegre a Recife, animando a propaganda antiescravista. Também não conseguira se aproximar de quadros políticos influentes, como Taunay, ou ter algum benefício prático de suas boas relaçôes com outros ex-políticos catarinenses, como Gama Rosa, por exemplo, que havia sido igualmente presidente da província em 1881, e, uma vez à frente do governo, cercara-se dos jovens intelectuais locais, inclusive Cruz e Sousa, tendo posteriormente se fixado no Rio, como diretor da Imprensa Nacional e Secretário da Escola Nacional de Belas Artes.

Grupos fechados de literatos e jornalistas, quase "famílias", e mais uma crítica que, como novo órgão republicano, brandia o mote da literatura nacional contra o lusitanismo que persistira sob o império, estreitaram o espaço de recepçáo a estrangeiros. E Cruz e Sousa era, por tudo, um "estrangeiro": pelo lugar de onde provinha, por sua cor de pele, no momento em que ferviam as controvérsias raciais, por seu reconhecido atrevimento em sociedade

\footnotetext{
${ }^{16}$ MUZART, Zahide Lupinacci. Cartas de Cruz e Sousa. Florianópolis: Letras Contemporâneas, 1993, p. 31.

${ }^{17}$ MAGALHÁEES Jr., Raimundo. Poesia e vida de Cruz e Sousa, op. cit.

${ }^{18}$ MUZART, Zahide Lupinacci. Cartas de Cruz e Sousa, op. cit., p. 34.
} 
amaneirada, ${ }^{19}$ e pelo manejo da estética simbolista ou, como se dizia, pelo seu esteticismo europeizante. De modo que, à diferença de André Rebouças, as ambiguidades decorrentes de sua posição não assaltariam a sua obra: excluído e hostilizado, Cruz e Sousa construiu uma poética em radical confronto com seus contemporâneos.

Confronto talvez não seja o termo; melhor seria incomunicabilidade. E nessa correção se observa a confluência entre vida e obra do autor, já que a incompreensão sentida por Cruz e Sousa desliza para o plano de sua expressáo simbolista, cuja poética anseia pelo inexprimível, o incomunicável. Em Cruz e Sousa, o desconforto com o mundo não se traduziu em uma denúncia explicitamente política das instituiçôes ou da sociedade, como em Rebouças, e tampouco organizou uma intervenção pública, uma literatura militante, como aspirava Lima Barreto. Caracterizou-o, diversamente, o registro lírico de um mundo torto, que vaga erraticamente à espera de uma nova linguagem, assimilando, portanto, o seu exílio individual àquele experimentado por toda a humanidade. Nesse sentido, racionalizou seu sentimento de exclusão a partir da tópica da espera, do momento em que todos os homens rememorariam sua transcendência mediante o único instrumento capaz de despertá-los - a poesia - o que lhe conferia, como poeta, papel superlativo e uma via de sublimaçáo da sua precariedade social e existencial.

Aspecto relevante a mencionar é o fato de Cruz e Sousa ter selecionado, naquele contexto, a gramática simbolista que, na Europa, buscou caracterizar a face lunar, demoníaca, da nascente experiência moderna. E o fazia como enredo e como estrutura do enredo, na medida em que não apenas anunciava o caos e a miséria trazidos pela derrota das forças sociais populares e a rotinização do mundo burguês, como também denunciava ser miserável a tentativa de falar sobre essa derrota, sobre o crescente desmantelo do mundo, com a linguagem disponível, isto é, com os recursos cognitivos análogos àquela experiência.

$\mathrm{Na}$ análise que empreendeu da obra de Cruz e Sousa, Roger Bastide chama a atenção para sua filiação ao simbolismo literário francês e para o platonismo que operava como alicerce invisível sobre o qual se equilibrava aquela poética. ${ }^{20} \mathrm{~A}$ questão, segundo o autor, é a da exigência de um retorno à unidade - a arché - a que só se chega pela experiência extática, e não pela racionalização dominante no mundo moderno. Portanto, sinteticamente, o simbolismo problematiza a representação, retira da poesia as amarras do naturalismo e, nessa dimensão, problematiza também a história. Foi essa poderosa crítica filosófica à ordem liberal-burguesa em seu nascedouro que chegou ao Brasil e alimentou uma determinada percepção dos impasses do moderno na periferia do capitalismo.

Assim, toma-se, aqui, a tópica da recusa à racionalização do mundo como via de acesso

\footnotetext{
${ }^{19}$ ANDRADE MURICY. Atualidade de Cruz e Sousa. In: Cruz e Sousa. Obra completa. Edição comemorativa do centenário. Rio de Janeiro: Aguilar, 1961, p. 17-64.

${ }^{20}$ BASTIDE, Roger. A poesia afro-brasileira. São Paulo: Martins, 1943.
} 
à poesia de Cruz e Sousa - uma via sociológica, bem entendido, que faz dele um crítico da cultura avant la lettre. É no poema "Emparedado" que se vê um diagnóstico acerca do desajuste brasileiro em relaçáo àquela que era considerada a única linguagem funcional à ordem e previsibilidade modernas - a ciência. Uma crítica da cultura, enfim, experimentada como fratura do poeta:

O temperamento que rugia, bramava dentro de mim, esse, que se operasse - precisava, pois tratados, toda a biblioteca de Alexandria, uma Babel e Babilônia de aplicaçóes científicas e de textos latinos para sarar... Tornava-se forçoso impor-lhe um compêndio [...] de geometria. O temperamento entortava muito para o lado África - era necessário fazê-lo endireitar inteiramente para o lado da Regra, até que o temperamento regulasse certo como um termômetro...

Cruz e Sousa viveu dez anos na capital federal. Em 1893, casou-se com Gavita, negra como ele e vítima de sucessivas crises nervosas, empregando-se como arquivista da Estrada de Ferro Central do Brasil. Teve quatro filhos, três deles falecidos na infância e o último, filho póstumo, morreu entre os 15 e 16 anos de idade. Publicou, em vida, três livros e morreu tuberculoso, em 1898, na mais completa indigência. Cruz e Sousa contava 37 anos de idade.

Mudado o regime político, o Brasil de que se despediu Cruz e Sousa e que seria o ambiente da produção literária de Lima Barreto assistiu também a uma mudança nas suas elites dirigentes. Salvo os casos de adaptaçáo reflexivamente justificada, como a do monarquista Joaquim Nabuco, que afirmou ser a pátria maior do que a monarquia, e as cooptaçóes inevitáveis de quadros da elite imperial, a proclamação da república trouxe à cena uma legião de intelectuais de novo tipo, oriunda das camadas médias urbanas e identificada com a ciência e a modernização econômico-social do país. Se o império havia conferido destaque aos temas da política, da institucionalizaçáo dos mecanismos de poder, da ordenação do mundo público, a república voltar-se-á para a sociedade, para as relaçóes mediadas pelo mercado e para os padrôes de diferenciação — racial, inclusive — que operam na estruturação da ordem moderna.

O contexto em que se inscreve Lima Barreto é, portanto, fenomenologicamente, muito diverso do que serviu à inscrição de Rebouças e Cruz e Sousa. Mudara o ritmo da sociedade, mudaram as expressóes da cultura material, os critérios de identificação social, a experimentação da vida urbana. A ideia de um Brasil inteiramente novo, em ruptura com o passado, alçara voo e alcançara o estrato dos intelectuais, que, de grupo imerso na dimensão pública, buscará alinhar-se pelo processo de constituição de um mercado de bens culturais. ${ }^{21}$

Porém, sob essa fenomenologia diversa, o mundo em que se moverá Lima Barreto é

\footnotetext{
${ }^{21}$ SEVCENKO, Nicolau. Literatura como missão. Tensôes sociais e criação cultural na Primeira República, São Paulo: Brasiliense, 1983.
} 
demarcado pelo tempo de seus antecessores. A começar pela percepção de sua experiência intelectual, a que não concedia ser individual, subjetiva, como pretendiam seus pares, sendo, antes, parte de um etos, de um modo de vida que valorizava a intelligentsia, seu papel público, e desprezava o arrivismo dos adventícios. Ao lado disso, Lima Barreto mantinha-se, existencial e intelectualmente, submerso no mundo popular, naquela fração da sociedade que, tornada progressivamente invisível pela reforma urbanística da capital federal, era o lastro profundo sobre o qual se assentava certo manejo intelectual da tradição. Por fim, seu humanitarismo e sua ênfase na solidariedade rearticulavam, numa tonalidade própria, a sugestão de Rebouças quanto a uma "monarquia democrática e integradora"; ou a de Cruz e Sousa, quanto a uma literatura rememorativa do que o Brasil burguês perdia ao ambicionar uma europeização que, justificada pela ciência, destruía referências mais antigas e mais vastas, como as provenientes da África.

A obra de Lima Barreto é tão extensa quanto a crítica que se debruçou sobre ela. Por isso, nesse passo final do texto é possível apenas apontar um caminho de aproximação com o campo político e intelectual de Rebouças e Cruz e Sousa, elegendo, para isso, o privilégio que Lima Barreto concede à ironia. É que a ironia é um recurso do cômico e uma construção integradora, na medida em que desestabiliza a verossimilhança de eventuais antagonistas, mediante a exageração de suas qualidades — o muito bom $\underline{v s}$ o muito mal. Visa, com isso, compreender a disputa não como a antessala da ruptura entre heróis inconciliáveis, mas como mero sintoma de um mundo em desordem. Nesse plano, a ironia em Lima Barreto não só sublinharia um ideal de integração social e racial no Brasil, como também indicaria uma operação crítica marcada pela autocontenção, isto é, uma crítica que deseja não a destruição do sistema, mas a sua inclusão nele.

Contudo, é preciso reconhecer que a ironia não é apenas o recurso conservador que desautoriza a existência do herói e evita a revolução. É também um modo de autoconhecimento social, pois ela desafia as representaçóes dominantes no mundo. ${ }^{22}$ Nesse plano, a ironia de Lima Barreto indica que o riso, o alívio pela conciliação, não é um ponto de chegada, mas, sim, uma crise, uma tomada de consciência quanto ao conflito de representaçôes e, portanto, uma constatação da natureza construída da realidade, abrindo aos homens a possibilidade de modelá-la. Assim, se a ironia nos concilia com os limites do mundo, é também por ela que se avança contra a ordem existente, em busca de um mundo melhor. Nessa tensão dentro-fora e na sua irresoluçáo reside o tema da incompletude brasileira, assumido, em Lima Barreto, como condição de possibilidade da sua própria existência.

Lima Barreto viveu por 41 anos, dividindo-se entre as atividades de amanuense do Ministério da Guerra e escritor. Sua vida foi marcada pela exclusão, pela solidão, pelo alcoolismo e, por fim, pela alienaçáo. Morreu em 1922, ano em que a Semana de Arte Moderna revestiu de simbolismo o desejo das elites brasileiras de se acertarem pelo re-

\footnotetext{
${ }^{22}$ HUTCHEON, Linda. Teoria e politica da ironia. Belo Horizonte: Editora UFMG, 2000.
} 
lógio moderno.

5.

Se pensados alinhadamente, Rebouças, Cruz e Sousa e Lima Barreto conformam, a despeito de suas diferenças, uma imagem de mundo discrepante da que era, entáo, assimilada como modelo para a reestruturaçáo do Brasil moderno: uma ontologia social centrada no indivíduo e no mercado autorregulado. Recusaram, em comum, a naturalização dos fatos, a adesão a uma ética social utilitária e a acomodação intelectual frente a uma representação homogênea do mundo - tônicas daquela nova civilização que se afirmava. Nesse sentido, a tragédia pessoal desses três negros, o seu miserável desfecho, é uma evidência da derrota da imaginação pública brasileira naquela quadra.

Rebouças, Cruz e Sousa e Lima Barreto conformam também o andamento da trajetória de pretos e mulatos cultos no Brasil, entre o fim do império, no último quarto do século XIX, e a estabilização institucional da república, após uma década de conflitos sangrentos e o extermínio de Canudos (1896-1897), ápice da violência do novo Estado republicano contra o mundo popular. Nesse andamento, a expressão do exílio que aqueles intelectuais experimentaram em seu próprio país conheceu um caminho de progressiva subjetivação. Rebouças, por exemplo, foi um tribuno, alguém que vivia o exílio com heroísmo e como uma espécie de certificação da sua honra; o exílio de Cruz e Sousa foi mais doloroso e indigente, experimentado como incomunicabilidade; finalmente, Lima Barreto inscreve o exílio em seu psiquismo, como estigma, marca de sua inadequação social e racial. Enfim, de tribuno a alguém que encarna a incomunicabilidade presente no mundo e, finalmente, a insano, a experimentação dos lugares da crítica em Rebouças, Cruz e Sousa e Lima Barreto é ilustrativa do definhamento progressivo da dimensão pública conferida pelo império aos intelectuais.

Os três conformam, ainda, uma representação do Brasil e dos brasileiros a contrapelo da percepção das elites locais, que, ecoando Joaquim Nabuco, ${ }^{23}$ apontaram a existência de um oceano inteiro a separar-nos da imaginação. "No século em que vivemos", disse Nabuco, "o espírito humano [...] está do outro lado do Atlântico; o Novo Mundo, para tudo que é imaginação estética ou histórica é uma solidão".

Em Rebouças, Cruz e Sousa e Lima Barreto a imaginação encontra outra morada: atravessa o oceano e se localiza no Brasil, onde tudo é construçáo, invençáo e aposta. Assim, a imaginaçáo de que falam deixa de ser apenas o lastro da sua experiência como intelectuais, estendendo-se também às figuras da sua criação: o produtor rural autônomo, em Rebouças, o poeta desperto do sono do mundo, em Cruz e Sousa, e o indivíduo solidário, em Lima Barreto. Livre, reflexivo e fraterno, o brasileiro modelado pela imaginação daqueles intelec-

${ }^{23}$ NABUCO, Joaquim. Minha formação. Rio de Janeiro: Topbooks, 2000. 
tuais é o esboço de outro mundo possível.

Conformam, por fim, um legado ideativo ainda em circulação na vida brasileira, embora cada vez mais esmaecido. Na contramão da síntese liberal-burguesa esboçada no republicanismo dos cafeicultores paulistas e ensaiada na Primeira República (1889-1930), Rebouças, Cruz e Sousa e Lima Barreto recusaram o lado solar do debate sobre a modernização que tinha curso no Ocidente europeu, as certezas nele contidas, o caminho rumo à jaula de ferro. $\mathrm{O}$ repertório de que lançaram mão sinalizava incerteza e incompletude. Dele se serviram, e assim esperavam servir ao Brasil.

\section{Referências bibliográficas}

ALONSO, Ângela. Ideias em movimento. A geração 1870 na crise do Brasil-Império. Rio de Janeiro: Paz e Terra, 2002.

ANDRADE MURICY. Cruz e Sousa. Obra Completa. Rio de Janeiro: Aguilar, 1961.

ASSIS BARBOSA, Francisco de. A vida de Lima Barreto (1881-1922). Rio de Janeiro: Civilização Brasileira, 1964.

BARBOZA Filho, Rubem. Tradição e artifício. Iberismo e barroco na formaçáo americana. Belo Horizonte: Editora da UFMG, 1999.

BASTIDE, Roger. A poesia afro-brasileira. São Paulo: Martins, 1943.

CARVALHO, José Murilo de. Os bestializados. O Rio de Janeiro e a república que não foi. São Paulo: Companhia das Letras, 1987.

CARVALHO, Maria Alice Rezende de. O quinto século. André Rebouças e a construção do Brasil. Rio de Janeiro: Revan, 1998.

. Intelectuales negros en el Brasil del siglo XI. In: ALTAMIRANO, Carlos; MYERS, Jorge (Org.). Historia de los Intelectuales en America Latina. 1. ed. Buenos Aires/Madri: Katz Editores, 2008, v. 1, p. 312-334.

André Rebouças e a questão da liberdad. In: BOTELHO, André; SCHWARCZ, Lilia Moritz (Org.). Um enigma chamado Brasil. 29 intérpretes e um país. São Paulo: Companhia das Letras, 2009, p. 48-59.

HUTCHEON, Linda. Teoria e politica da ironia. Belo Horizonte: Editora UFMG, 2000. MAGAlHÁES JR., Raymundo. Poesia e vida de Cruz e Sousa. São Paulo: Editora das Américas, 1975.

MATOSO, Katia. Babia - século XIX. Uma província no império. Rio de Janeiro: Nova Fronteira, 1992.

MERQUIOR, José Guilherme. De Anchieta a Euclides: breve história da literatura brasileira. 
Rio de Janeiro: José Olympio, 1977.

MUZART, Zahide Luoinacci. Cartas de Cruz e Sousa. Florianópolis: Letras Contemporâneas, 1993.

NABUCO, Joaquim. Minha formação. Rio de Janeiro, Topbooks, 2000.

SCHWARCZ, Lilia. M. O espetáculo das raças: cientistas, instituiçôes e a questão racial no Brasil, 1870-1930, São Paulo: Companhia das Letras, 1993.

SEVCENKO, Nicolau, Literatura como missão. Tensôes sociais e criaçâo cultural na Primeira República, São Paulo: Brasiliense, 1983.

SKINNER, Quentin. Liberdade antes do liberalismo. São Paulo: Editora Unesp, 1999.

SPITZER, Leo. Lives in Between. Assimilation and Marginality in Austria, Brazil, West Africa. Cambridge: Cambridge University Press, 1989.

VERÍSSIMO, Inácio José. André Rebouças através de sua autobiografia. Rio de Janeiro: José Olympio Editora, 1939. 